\title{
Morphosyntactic knowledge of clitics by Portuguese heritage bilinguals*
}

\author{
ESTHER RINKE \\ Goethe-University Frankfurt, Germany \\ CRISTINA FLORES \\ University of Minho, Portugal
}

(Received: February 25, 2013; final revision received: November 18, 2013; accepted: November 18, 2013)

This paper focuses on the linguistic competence of adult Portuguese-German bilinguals in their heritage language, European Portuguese (EP), which they acquired at home in early childhood in the context of German as the majority language. Based on a grammaticality judgment test, we investigate their morphosyntactic knowledge of clitics. The central questions are whether possible deviations from native monolinguals may be traced back to a) lack of contact with the formal register; b) reduced input after preschool age; and c) cross-linguistic influence. The results reveal qualitative differences between the heritage speakers and a group of monolingual controls in almost all test conditions. We conclude that although the linguistic knowledge of the heritage bilinguals investigated in this study differs from that of monolinguals, it is not "deficient" but "different" and "innovative", because it is primarily based on the spoken variety of the language and because it promotes linguistic changes which are inherent in the speech of native monolinguals.

Keywords: clitics, European Portuguese, bilingual language acquisition, heritage speakers

\section{Introduction}

Although research on heritage bilingualism has received increasing attention in the last decade, this does not mean that researchers have detected a previously unknown group of speakers. Heritage speakers (HSs) are bilingual speakers who were studied as early bilinguals long before the term HERITAGE BILINGUALISM came into use in the field of language acquisition. Studies on bilingual language acquisition have shown that a normal developing child who is exposed regularly to two languages from a very early age will acquire two native languages in a similar way and within a nearly identical time frame as two monolingual children acquire those languages (Meisel, 2001). Although cross-linguistic influence may play a role in this process (Müller \& Hulk, 2001) and there might be considerable variation in the input that bilingual children receive, biological or cognitive maturation enables successful bilingual language acquisition (Genesee \& Nicoladis, 2006).

Nevertheless, research on heritage language (HL) acquisition has provided consistent evidence for the fact that HSs differ from native speakers both in production and comprehension of the target language (e.g. Au, Knightly, Jun \& Oh, 2002; Keating, VanPatten \& Jegerski, 2011; Kim, Montrul \& Yoon, 2009; Montrul, 2004, 2008,

\footnotetext{
* This research was supported by a Portuguese-German cooperation grant, funded by the DAAD (German Academic Exchange Service) and the CRUP (Council of Portuguese Universities) [grant numbers 50097448 and A-18/10 AI-A/09]. We would like to thank Pilar Barbosa and Tanja Kupisch for their help in preparing the tests.
}

2010a, 2010b; O’Grady, Lee \& Choo, 2001; Polinsky, 2006, 2008, 2011; Rothman, 2007; Silva-Corvalán, 1994). One of the most challenging aims of the research on HL acquisition is therefore to understand if and, if so, why HSs differ from monolingual native speakers.

This study addresses these questions by focusing on a population which has not yet received sufficient attention: HSs of European Portuguese (EP) growing up in a dominant German environment. This study analyses their knowledge of clitics - a very complex pattern in EP grammar - on the basis of a grammaticality judgment test.

The paper is organised as follows: in section 2 , we outline some of the chief questions related to heritage bilingualism and address some recent outcomes of research on HSs of EP. Section 3 first presents the main characteristics of the EP clitic system, and then discusses its implications for language acquisition. The research questions and hypotheses are discussed in section 4 . Section 5 presents the participants and the grammaticality judgment test. Section 6 displays the results of both informant groups, the HSs and a group of monolingual controls, which are discussed in section 7.

\section{Heritage bilingualism}

\subsection{Heritage language acquisition}

If HSs acquire their languages naturally in childhood, what makes HL acquisition a special type of bilingualism?

What chiefly distinguishes heritage bilingualism is the split in the acquisition setting. Pascual y Cabo and

Address for correspondence:

Prof. Dr. Esther Rinke, Goethe Universität Frankfurt, Institut für romanische Sprachen und Literaturen, Grüneburgplatz 1, 60629 Frankfurt

Esther.rinke@em.uni-frankfurt.de 
Rothman (2012, p. 450) point out that "to qualify as HS bilingualism, acquisition crucially must take place in a situation where the home language is decisively not the language of the larger culture". The HL is the L1 of second-generation migrants born to first-generation parents, who were themselves born in their home country. In general, in the first years of life the young immigrant child comes into contact almost exclusively with the HL, shifting towards the majority language at the expense of the HL at the time of entering (pre)school. Because the home language is a minority language, access to formal education in the $\mathrm{HL}$ is restricted. This means that, in the first years of life, HL acquisition is the same in terms of input as the $\mathrm{L} 1$ acquisition of monolingual native speakers. The heritage child, like the monolingual L1 child, is exposed to oral input in a familial context. Differences between $\mathrm{HL}$ and monolingual $\mathrm{L} 1$ acquisition start between the ages of three to six, when exposure to the language of the dominant environment increases and the immigrant child becomes literate in that language. By the age of seven or eight the heritage child has restricted opportunities to use her/his HL in socially diverse contexts and different language registers, since the $\mathrm{HL}$ is mostly used at home in an everyday routine setting for a few hours.

The role of input has long been recognised as a crucial variable in language acquisition (Unsworth, 2013). Studies of simultaneous bilinguals have shown that bilingual children who have less consistent input in one language develop a weaker language, which is different in some aspects from the stronger language (Schlyter, 1993; Unsworth, 2013). Several authors suggest that children need to be exposed to a certain amount of input in order to acquire language. In the case of bilingual children, it has been suggested that if they have significantly less input from one language, they will take longer to acquire certain structures, because they will require more time to gain the "critical mass" needed to trigger acquisition (Gathercole, 2007; Oller \& Eilers, 2002; Unsworth, 2013). Research in the field of language attrition has reinforced the importance of language exposure, especially in the period before puberty (Flores, 2010, 2012; Kaufman \& Aronoff, 1991; Seliger, 1989). Flores (2010, 2012), for instance, argues that bilingual children need to be exposed to both languages until the age of 10 to 12 years. If the child loses contact with one language before this phase, the unused or less used language will undergo attrition. Kupisch (2012) suggests that properties which are acquired late can be especially vulnerable in multiple first language acquisition. This reasoning is based on Meisel's (2011) assumption of at least two clusters of sensitive phases after which the optimal conditions for language acquisition slowly start to fade out (one around the age of 4;0, the other around 7;0). Kupisch (2012) concludes that under changing input conditions, some phenomena that are typically acquired at school age (e.g. generic reference) may not be acquired successfully by heritage speakers.

In the case of HL acquisition this means that the heritage child is still developing her/his first language when the input conditions are no longer optimal. The key question is whether the input conditions that apply at a later age are still sufficient to enable the further development of the HL like a native language, or whether the development of the HL diverges from this point on. In fact, many studies which focus on heritage speakers have shown that the language competence of heritage bilinguals diverges with respect to native speakers' competence (for an overview see Montrul, 2008). In their study on EnglishWelsh speakers, Gathercole and Thomas (2009) measured the amount of input from both languages and related this variable to the performance of the speakers in a wide range of tests. The authors demonstrate that, for a minority language, the input levels in that language are directly related to the ultimate abilities of the speakers. All speakers with higher levels of input, i.e. speakers who seemed to have reached a "critical mass" of input, showed better linguistic performance. Furthermore, the authors suggest that for the minority language there is a need for continued exposure throughout life in order to reach and maintain full command of this language. Unsworth (2013) reinforces the importance of continued language exposure as a guarantee of successful bilingual acquisition. She argues that it is not (only) the quantity of input in the first years of life that influences the acquisition process, but the prolonged "cumulative" exposure over the course of the speaker's life.

In addition to the quantity of input, its quality may also have an influence on the linguistic competence of HSs. Of course, in the case of migrant communities, the input that second generation children receive in their HL comes mainly from the first generation. Studies of L1 attrition have shown that first generation adult migrants may experience this after living in the host country for several decades (Tsimpli, Sorace, Heycock \& Filiaci, 2004), even though, in this population, attrition effects are selective and not very expressive. This means that the input received by second generation children may be subject to some attrition and foster the acquisition of a slightly different grammar.

Additional variables that are directly linked with the "input" factor are "schooling" and "exposure to formal language registers". While humans do not need schooling in order to acquire language, it is well documented that literacy skills help to stabilise their language competence (see discussion in Oller \& Eilers, 2002). Literacy and formal instruction also promote metalinguistic ability (Erlam, 2013). Additionally, all languages have structures that are rare in their spoken varieties; native speakers come into contact with them mostly via written texts and when they use more formal language registers. It is precisely in school that children are exposed to such texts and registers. 
They start to use language outside the familiar context of daily oral communication and extend it to socially diverse contexts, using different language resources. Since HSs are mainly exposed to spoken varieties of their $\mathrm{HL}$ and have reduced (or no) formal instruction, they do not have the opportunity to come into contact with more formal language registers. This means that they lack an important language support which fosters linguistic abilities. Furthermore, some studies of HL acquisition have tested the interface hypothesis $(\mathrm{IH})$ proposed by Sorace and colleagues (Sorace, 2004, 2011; Tsimpli et al., 2004), which claims that linguistic phenomena at the interfaces, such as the syntax-discourse or syntaxsemantics interface, are more susceptible to crosslinguistic influence in language attrition and bilingual L1 acquisition than other aspects of grammar. Although, originally, the IH did not refer to HSs (see Sorace, 2011), Montrul and Polinsky (2011) argue that it is reasonable to extend the hypothesis to this group of bilingual speakers, since the aspects that cause problems for L2 learners appear to be those that are protracted in HL acquisition. Montrul (2010a), who compares L2 learners of Spanish and Spanish HSs with regard to their knowledge of Spanish clitics, clitic left dislocations and differential object marking, notes that both populations show more robust knowledge of core aspects of grammar than of aspects of the syntax-semantics/discourse interface. Keating, VanPatten and Jegerski (2011), who tested HSs' and advanced L2 learners' knowledge of null and overt subjects in Spanish, point to similar conclusions.

\subsection{Studies on heritage speakers of European Portuguese}

Until now, there have been only a few studies of the linguistic competence of EP HSs (Flores \& Barbosa, 2012; Pires \& Rothman, 2009; Santos \& Flores, 2012; Senra, 2011).

Senra (2011), who analyses the proficiency of adult Portuguese second generation migrants living in Germany with respect to their knowledge of the Portuguese tense system, confirms that adult HSs of EP have native-like knowledge of the EP tense system, though they make some errors related to aspect (perfective - imperfective distinction) which do not occur in monolingual speech. Pires and Rothman (2009), investigating knowledge of inflected infinitives in Portuguese and Brazilian HSs, found that the EP HSs have full morphosyntactic and semantic competence with regard to this property, but the Brazilian group lacks knowledge of inflected infinitives. The authors attribute this competence mismatch to different input conditions for the two HS groups. Since inflected infinitives are no longer instantiated in Brazilian Portuguese (BP) colloquial dialects, Brazilian HSs who do not have access to a formal variety of BP do not have sufficient input to acquire this property. In contrast, inflected infinitives are present in all dialects and registers of EP, so the input available to EP HSs robustly exemplifies inflected infinitives and triggers their acquisition.

Santos and Flores (2012) analyse knowledge of adverb placement and VP ellipsis, a property that has been used as evidence for early L1 acquisition of verb movement. The results of their study show that heritage children do not differ significantly from monolingual children in the production of VP ellipsis.

In contrast to VP ellipsis, pronominal object clitic placement is one of the most intricate issues in the grammar of EP. Studies on the acquisition of clitics by monolingual EP children (Costa, Fiéis \& Lobo, in press; Duarte, Matos \& Faria, 1995) have shown that clitic placement is acquired very late in EP (around the age of six or seven). Flores and Barbosa (2012), who have studied the competence of Portuguese HSs living in Germany with respect to clitic placement in EP, demonstrate that HSs go through stages in the acquisition of clitic placement similar to those of monolingual EP children, though they take longer to attain the target grammar. The results of both studies indicate that structures which tend to be acquired later in L1 acquisition may be affected by input shift, whereas early-acquired properties tend to be fixed before the exposure to the home language begins to decrease significantly. Nevertheless, adult HSs do not appear to have a divergent grammar with respect to the two properties.

Investigating the knowledge of object clitics in HSs of EP in Germany is of special interest because German, the bilinguals' stronger language, does not have clitic pronouns. ${ }^{1}$ In addition, EP clitics have a number of special properties that set them apart not only from strong and weak pronouns but also from the object clitics of other Romance languages such as Spanish, where their acquisition seems to represent no major problem for even low proficiency HSs (Montrul, 2010b). In addition, EP systematically shows null objects in main clauses - an option that interacts with the distribution of object clitics.

In the following section, we will present and discuss the main characteristics of the EP system of object clitics in more detail, to identify the properties of the target system and clarify the tasks for the language acquirer.

\section{Linguistic background}

\subsection{Clitics in European Portuguese}

EP, like other Romance languages, possesses a system of weak (clitic) and strong object pronouns for direct as well as indirect objects. Strong pronominal forms, e.g. of the

\footnotetext{
1 Standard German has only strong pronominal objects and weak expletives and the clitics in German colloquial dialects are different from the pronominal clitics of EP.
} 
third person are ele (3rd person singular masculine), ela (3rd person singular feminine), eles (3rd person plural masculine) and elas (3rd person plural feminine). Object clitics show more morphological distinctions than strong object pronouns, e.g. case distinctions ( $a$ (3rd person singular feminine) $/ o$ ( 3 rd person singular masculine) for accusative and the (3rd person singular) for dative). In addition, enclitic accusative forms can have a different shape depending on the ending of the verb to which they attach. With nasals, $-o(s) /-a(s)$ become $-n o(s) /-n a(s)$; with $-r$ (e.g. infinitival verbs) and with $-s$ (2nd person singular and 1 st person plural), $-o(s) /-a(s)$ become $-l o(s) /-l a(s)$ and $-r /-s$ drops.

The clitic forms also differ from their strong counterparts with respect to a number of syntactic properties. Unlike strong forms, clitics cannot occur in isolation or be separated from their host and they cannot participate in syntactic operations like dislocation, coordination or modification. Therefore, clitics, in contrast to strong pronominal forms, are not independent syntactic categories (XP-elements). Because of their bound character, they have been analysed as syntactic heads $\left(\mathrm{X}^{\circ}\right)$ fulfilling the function of agreement markers (e.g. Fernández Soriano, 1999; Franco, 2000; Suñer, 1988). We cannot go into the details of this discussion, but one interesting aspect of the agreement-like nature of object clitics is that they always accompany strong pronominal objects and can resume a dislocated noun phrase in topicalisation constructions.

In contrast to other Romance languages, the direction of attachment of EP object clitics relates to a number of construction-specific properties (e.g. Barbosa, 1996, 2008; Martins, 1994; Raposo, 2000), the most relevant of which we will discuss in section 5.2. Here, we will only mention that EP object clitics vary between ENCLITIC placement in main clauses with a preverbal subject or a topic element and PROCLITIC placement in subordinate clauses and with sentence negation (Barbosa, 1996, 2008). In some contexts, e.g. with auxiliaries and modal verbs, the clitic may either occupy the postverbal position to the right of the infinitive or 'climb up' to the right of the finite modal verb (optional CLITIC CLIMBING).

To sum up, the native speaker's knowledge of clitics in EP includes not only the differences between clitic and strong pronominal elements but also the variable options for the form and placement of object clitics. One could conclude that the acquisition of object clitics in EP is a more complex task than in Spanish, because of its internal variability. ${ }^{2}$ The complexity and variability of EP object clitics might also affect the morphosyntactic knowledge of

2 C.f. Costa and Lobo (2007), who argue that the L1 acquisition of Portuguese clitics is protracted in comparison to that of Spanish and/or French and that children acquiring object clitics in EP produce higher omission rates. clitics by Portuguese heritage bilinguals. In the following section, we will provide an overview of what is known about the L1 acquisition of clitics in EP.

\subsection{L1 acquisition of clitics in EP}

Research on the acquisition of object pronouns in several Romance languages has shown that in $\mathrm{L} 1$ acquisition the production of clitics is preceded by a phase during which children omit the clitic pronouns (Wexler, Gavarró \& Torrens, 2004). Monolingual Portuguese children produce significantly higher rates of null objects and the period of target-deviant omissions is more extended than in other languages with object clitics. According to Costa and Lobo $(2007,2011)$ this difference can be traced back to the null object parameter. Since EP allows for null objects in main clauses (Raposo, 1986), Portuguese children seem to overgeneralise this parametric option to embedded contexts which do not allow null objects in the adult grammar. Thus, by the age of five or six, monolingual Portuguese children have still not acquired all conditions that govern the realisation of object pronouns in EP (Costa \& Lobo, 2011: 205).

Acquiring the clitic system of EP also implies mastering clitic placement, a property which is particularly complex since the variation between proclisis and enclisis is dependent on a large set of triggers. Recent experimental work on the acquisition of clitic placement in EP has shown that at the age of seven EP children still overgeneralise enclitic constructions, especially in adverbial clauses and sentences with quantified subjects (Costa et al., in press). Clitic placement is thus a further property that is stabilised very late and, consequently, contributes to the protracted development of the clitic system per se in EP acquisition.

Finally, the variation in the shaped forms of the object pronoun in enclitic constructions should be mentioned. As was shown in the previous section, in postverbal position the clitic pronoun can be realised as 'o/a/os/as', as 'lo/la/los/las' or as 'no/na/nos/nas', depending on the verbal ending. To our knowledge no study has focused on the acquisition of these pronominal forms in EP but, given the complexity of the clitic system and the delay in the acquisition of other properties, one can conclude that the contracted forms of the clitics may also be acquired only at a later stage of development. This issue is explicitly taught at school after the fifth grade. However, it is important to note that teachers of the Portuguese language report that pupils tend to fail to choose the appropriate enclitic form until they reach high levels of schooling. The choice of the right morphological form of the enclitic pronoun therefore seems to be a property which is consolidated through formal education and mastered only by older EP children. 


\section{Research question, hypotheses and methodology}

The central question of this paper is whether HSs' grammatical knowledge of clitics differs from that of adult monolingual native speakers. If any differences emerge, we will have to go further into the question of which parts of the grammatical domain under investigation are affected and how the differences between the two groups of speakers may be explained.

Such differences, however, cannot be assumed a priori. Because bilingual L1 acquisition does not differ qualitatively from monolingual L1 acquisition and given the fact that heritage bilinguals do not differ from native monolinguals with respect to their age of onset of language acquisition, one can conclude that in fact no differences are to be expected. The first hypothesis that we will pursue here is therefore the following:

I. If age of onset of acquisition is the decisive factor determining the acquisition of clitic pronouns in Portuguese, we expect no qualitative differences between native monolingual speakers and heritage bilinguals.

However, studies on the linguistic competence of HS have shown that they may indeed differ from native monolinguals. Three factors have been highlighted: a) reduced contact with the formal register; $b$ ) reduced input after preschool age; and c) cross-linguistic influence. If we find differences between HSs and native monolinguals, we will have to ask whether they can be attributed to these three factors. In order to answer this question, we have developed a grammaticality judgment task that includes different conditions relating to different aspects of the knowledge of clitics. Below, we will formulate the corresponding hypotheses and provide examples of the evidence that allows us to disentangle the role of the different factors.

II.a) If lack of formal education and reduced contact with formal register play a role, we expect HSs to show a weaker knowledge of forms or constructions that occur predominantly in the formal register. Reduced access to the formal register can also translate into reduced lexical knowledge.

Formal education is reflected in, for instance, superior knowledge of the contracted forms of the clitic pronoun (e.g. -nos instead of -os after a verb ending in a nasal), because these morphologically deviant forms are trained and corrected at school.

Exposure to different language registers and sources (formal registers; written sources) also manifests itself in lexical knowledge. This is reflected in, for instance, knowledge of the different clitic forms and their use depending on the valency or subcategorisation frame of the verb. Speakers lacking this knowledge might accept dative clitics in contexts where the verb requires an accusative form, because this option exists in colloquial speech.

The second factor that may cause differences between HSs and monolinguals is reduced input after preschool age.

II.b) If reduced input plays a role, we expect properties that are acquired later to be more problematic than properties that are acquired in early childhood.

As we discussed in section 3.2, studies on the acquisition of clitics in Portuguese have shown that EP children misplace clitics until late stages of acquisition. Costa et al. (in press) show that the first proclitic context to be acquired is negation, but even this context is not mastered until the age of five. Flores and Barbosa (2012) demonstrate that the acquisition of clitic placement is even more delayed in HL development, but heritage children effectively develop knowledge of all proclitic triggers (although at a more advanced age and showing more variation). So, if reduced input indeed plays a role, clitic placement might remain a vulnerable syntactic domain. HSs could show deviations from the judgments of adult native speakers: in particular, they may show a bias towards the enclitic placement options.

The third factor that we should take into consideration is cross-linguistic influence.

II.c) If cross-linguistic influence plays a role, we would expect that HSs, when faced with optionality, will tend to use a grammatical option that also exists in their German grammar.

Optionality may arise in contexts of clitic climbing. Although in EP the clitic can either occupy the position to the right (1b) or to the left (1a) of the infinitive (optional CLITIC CLIMBING), there seems to be a growing tendency in monolingual EP speakers to reject the option '(SEMI)AUXILIARY-CLITIC-INFINITIVE', especially with modal verbs like poder ('can'). This can be attributed to formal education, because school teachers often correct the 'climbed order', and/or it may be the outcome of sociolinguistic variation. As an anonymous reviewer pointed out, northern dialects of EP accept enclisis to the modal verb (clitic climbing) less than southern dialects. Although our participants are all from the north of Portugal, and regardless of the source of this tendency in native EP speakers, heritage bilinguals could show a preference for clitic climbing because it reflects the German surface order (kann es machen - 'can it do') and 
in turn reject the option '(SEMI)AUXILIARY-INFINITIVECLITIC', since it is not grammatical in German $\left({ }^{*}\right.$ kann machen es - 'can do it').

(1) a. Hoje não consegui fazer o teu bolo today not managed to make the your cake preferido, mas posso-o fazer amanhã. preferred but (I) can-it clitic $_{\text {do tomorrow }}$ "Today I didn't manage to make your cake but I can do it tomorrow."

b. Hoje não consegui fazer o teu bolo today not managed to make the your cake preferido, mas posso fazê-lo amanhã preferred but (I) can do-it clitic $_{\text {tomorrow }}$ "Today I didn't manage to make your cake but I can do it tomorrow."

Although cross-linguistic influence in HL acquisition has not yet been sufficiently studied, it has been shown that direct transfer of structures from the dominant language is less frequent than expected (Montrul, 2010a; Santos \& Flores, 2012). However, given the fact that German has no object clitics, heritage bilinguals could accept sentences with strong pronominal objects without a clitic, although this option is not grammatical in Portuguese.

The last hypothesis looks at possible competence differences related to the type of structure.

II.d) Given the fact that studies on language attrition have shown that the syntax-discourse interface is vulnerable to cross-linguistic influence (Sorace, 2004; Tsimpli et al., 2004), we may also expect those phenomena to be more problematic than purely syntactic phenomena.

If phenomena at the interface of syntax and discourse are vulnerable, HSs could deviate from monolinguals in their knowledge of topicalisation structures in Portuguese. According to Duarte (1987), Portuguese has two topicalisation constructions, one with a resumptive clitic [Deslocação à Esquerda Clitica, clitic left dislocation, see (2a)] and one without [Topicalização, topicalisation, see (2b)]. The two constructions have different discourse functions, which will not be discussed in detail here (for further discussion, see Duarte (1987, 1996)). The crucial question is whether heritage bilinguals, like native monolinguals, have both options at their disposal.

(2) a. Estas prendas, comprei-as no these presents (I) bought-them clitic $_{\text {in-the }}$ centro comercial. shopping centre

"These presents, I bought them in the shopping centre." b. A Maria não gosta de ler, mas esse the Mary not likes to read but this livro leu com muito interesse. book (she) read with great interest "Mary doesn't like to read, but this book she read with great interest."

To sum up: the aim of our study is to investigate possible deviations in the HSs' knowledge of clitics from that of native monolinguals. The null hypothesis would be that heritage bilinguals do not deviate from native monolinguals, because both groups of speakers are exposed to Portuguese as a first language from birth. If, however, differences arise, they may be traced back to a range of factors, such as a) a lack of formal education or contact with the formal register; b) reduced input after preschool age; c) cross-linguistic influence and d) the nature of the syntactic domain. We will investigate which of those factors is indeed relevant.

In the next section, we will give an overview of the participants in our study and describe the design of the test in more detail.

\section{The study}

\subsection{Participants}

A total of 36 informants participated in the present study: 18 monolingually-raised native speakers of EP and $18 \mathrm{HSs}$ of EP, who were raised bilingually in Germany and have lived there since birth or early childhood.

The HSs completed a detailed questionnaire, focused on sociolinguistic and biographical information such as age at testing, age of migration, amount of formal instruction in Portuguese, language habits, amount and type of contact with EP and knowledge of other languages. Additionally, they were asked to rate their proficiency in German and Portuguese in different language skills (speaking, writing, understanding and pronunciation). The group of HSs comprises (eight male and ten female) adolescents and adults with ages ranging from 14 to 43 (mean age $=27.17$; standard deviation $[\mathrm{SD}]=$ 7.94). Thirteen speakers were born in Germany to first generation Portuguese parents (all born in Portugal); the other five participants immigrated to Germany with their families in early childhood (before the age of five). All heritage bilinguals were exposed to Portuguese from birth and to German before the age of five at the latest. All participants reported using Portuguese as one of their home languages. However, in all cases, Portuguese is not their exclusive mode of communication within familial contexts, since all informants also mentioned the use of German. The majority of the heritage bilinguals $(\mathrm{n}=$ 14) report having frequent, daily contact with Portuguese. Four participants have less exposure to their HL at the time 
of testing, since they live alone and meet their families less frequently. All speakers visit Portugal every year in the holidays. Exposure to Portuguese is mainly restricted to oral input - no informants report reading literature or newspapers in Portuguese. The only contact with the written register is the special programme of instruction for heritage children, organised by the Instituto Camões ${ }^{3}$. In these courses students become literate in Portuguese and are also taught Portuguese history and geography. The extra-curricular classes take place in the afternoon or Saturday mornings, approximately two to four hours per week. All the informants were/are enrolled in these HL courses for seven to 12 years $($ mean $=9.22$; $\mathrm{SD}=$ 1.48). The two youngest participants (aged 14) are still attending a HL class (in the 7th and 8th grades); the older ones discontinued them by the age of 16 or 17 at the latest. All HSs are originally from the north of Portugal, thus avoiding the influence of dialectical variation on the results. ${ }^{4}$ Although Portuguese is present in daily interaction, all participants claimed to be Germandominant and to feel much more comfortable speaking German than Portuguese.

The control group comprises eight male and ten female native speakers of EP, who live in the north of Portugal. The HSs and monolingual controls are broadly from the same region. No informant in this group had been raised bilingually or lived outside Portugal for an extended period of time. The informants' ages range from 15 to 49 (mean age $=27.67 ; \mathrm{SD}=11.27$ ). The majority of the controls $(=11)$ have a low level of education, having completed six (or nine) years of schooling. The others have finished high school (12 years of schooling). None of them has completed a university degree. Given the fact that the group of HSs is not regularly exposed to formal education in Portuguese, the choice of native speakers with low formal education avoids the two groups differing too strongly with respect to formal instruction in Portuguese. In particular, both groups have a similar socio-economic status, which may be characterised as lower middle class.

\subsection{Test design}

In order to test the knowledge of clitics in both groups, we conducted a grammaticality judgment task, partly based on Montrul's (2010b) test for Spanish. The test included 115 grammatical and ungrammatical Portuguese sentences. It was divided into 23 sentence types (and

3 Instituto Camões is an administratively autonomous institution, which functions under the supervision of the Portuguese Government, aiming at world-wide promotion of the Portuguese language and culture. http://www.instituto-camoes.pt/.

4 Magro (2007) has shown that there is some dialectal variation in the realization of clitics, especially between northern and southern varieties of EP. subtypes) with five tokens per type. Twelve sentence types represented an ungrammatical condition and eleven a grammatical condition. Each target sentence was preceded by a context sentence.

The test was conducted as a paper and pencil test, completed individually in the presence of a research assistant. The sentences were randomised and the participants were asked to judge whether the sentence "sounds well" or sounds bad to them (binary responses). They were asked to judge the sentences as intuitively as possible and not to go back for comparative reasons. In order to avoid the participants rejecting examples for lexical or semantic reasons, they were asked to correct all the sentences they judged as ungrammatical. The test was not timed and took approximately 30 minutes to complete.

By relying on an offline grammaticality judgment test we intend to analyse the speakers' grammatical knowledge (competence). This technique has the advantage of avoiding interference with processing phenomena and targets the specific constructions under consideration. On the other hand it has the disadvantage of not covering real-time language use. It also allows the participants to incorporate metalinguistic knowledge into their judgments (see Bolger \& Zapata, 2011, for an interesting discussion on this issue). It appears from previous research on this topic (e.g. Lesaux \& Siegel, 2003) that heritage bilinguals show lower metalinguistic abilities than monolingual native speakers. This is mirrored in the well-documented tendency of heritage bilinguals to over-accept ungrammatical options. Based on this general finding, we expect to find less accurate results in the ungrammatical conditions (i.e. greater acceptance of ungrammatical structures) than in the grammatical ones. This difference will be visible in both experimental groups, but more salient in the HSs. We will consider this mismatch when discussing the results.

\section{Results}

In the following section we will present the details of the test and the results by showing the rates of accuracy. Before going into detail and discussing the accuracy means by sentence type per group, we will start by demonstrating the overall performance of the participants and the intergroup variation. Since the difference between the samples is not normally distributed, we will use non-parametric Mann-Whitney U-tests for the statistical analyses.

\section{Overall performance}

Table 1 shows the overall accuracy scores per group (in percentages).

The mean level of accuracy is about $91.96 \%(\mathrm{SD}=$ 4.40 ) in the group of monolingual native speakers, ranging 
Table 1. Mean accuracy, standard deviation, minimum and maximum per group.

\begin{tabular}{lccccc}
\hline \hline Group & $\mathrm{N}$ & Mean & Std. Deviation & Min. & Max. \\
\hline Monolingual & 18 & 91.96 & 4.40 & 85.22 & 99.13 \\
Heritage & 18 & 67.02 & 14.36 & 43.26 & 91.30 \\
\hline \hline
\end{tabular}

from a minimum of $85.22 \%$ to a maximum of $99.13 \%$. In the HS group the mean level of accuracy is about $67.02 \%$; however, the standard deviation is considerably higher in this case $(\mathrm{SD}=14.36)$, the minimum and maximum values ranging from $43.26 \%$ to $91.30 \%$. This indicates a large amount of intergroup variation; some heritage bilinguals show similar levels of accuracy as monolingual speakers (over 80\%) and others score very poorly, with less than $50 \%$ accurate responses.

A Mann-Whitney U-test was conducted to evaluate the overall differences between the two experimental groups. The results reveal highly significant differences between the monolinguals and the HSs $(U=9.50, p=.000)$, showing a clear disadvantage for the HSs. These overall results confirm the conclusions reached in other studies on HL acquisition (Au et al., 2002; Montrul, 2010a; Pires \& Rothman, 2009), which claim that HSs are less proficient than native speakers. However, as discussed above, it is vital to check whether the differences concern all grammatical conditions related to the production of clitics or whether some properties are more vulnerable than others.

\section{Performance per condition type}

In this section we will go through the results, describing the performance of both groups per condition type.

The conditions "employment of the right clitic form" and "morphological shape" tested morphophonological and lexical knowledge as well as knowledge partly acquired through contact with the formal register. The first condition had two sub-conditions: Type 1a) accusative clitic instead of dative (ungrammatical, see (3a)) and Type 1b) dative instead of accusative (ungrammatical, see $(3 b)$ ). The verbs used in condition 1a) were dar ('to give'), oferecer ('to offer') and enviar ('to send'); and in condition 1b) chumbar ('to fail'), ver ('to see'), ler ('to read') and assassinar ('to murder').

(3) a. (A Maria fez anos ontem.) *O João
(the Mary did years yesterday) the John
deu-a um livro.
gave-her clitic a book $_{\text {"Yesterday was Maria's birthday. John gave }}$
her a book."
b. (O Francisco
não estudou para
(the Francis
not studied for
o teste de Matemática.)
the test of mathematics)
*O professor
chumbou-lhe.
the teacher failed-him clitic $_{\text {. }}$
"Francis didn't study for the maths exam.
His teacher failed him."

Table 2 shows the mean level of accuracy (and the standard deviation) in both sub-conditions, i.e. the ungrammatical use of an accusative in a context which requires a dative clitic, and the use of a dative instead of an accusative clitic.

First, it is interesting that the mean correct judgment is $100 \%$ in both conditions in the control group. No monolingual informant accepts the use of an accusative instead of a dative clitic or vice versa. The mean for accuracy is significantly lower in the HS group. The HSs reject the ungrammatical employment of an accusative instead of a dative clitic in $70 \%$ of all contexts (SD = 35.15). Similar results are obtained in the inverse condition, in which the HSs achieve a mean rate of $71.11 \%$ $(\mathrm{SD}=41.29)$ accuracy. A non-parametric Mann-Whitney test shows significant differences between both groups in conditions Type $1 \mathrm{a}(U=72.00, p=.000)$ and Type $1 \mathrm{~b}$ $(U=99.00, p=.004)$.

The variation within the group of HS is very high. Seven speakers show $100 \%$ correct judgments in both subtypes: they perform just like the monolingual native speakers. Five HSs accept at least one ungrammatical sentence in only one of the ungrammatical sub-conditions, predominantly in Type 1a (employment of accusative instead of dative), attaining 100\% accuracy in the other condition (where they correctly reject the employment of dative clitics instead of accusatives). However, none of these speakers accepts the ungrammatical option in all sentences. Seven heritage bilinguals accept ungrammatical sentences in both sub-conditions, and again in this case none accepts the ungrammatical option in all contexts. This means that these speakers show uncertainty in their judgments, rather than a consistent acceptance of ungrammatical structures.

We believe these results do not show that the HS do not KNOW the appropriate form of the accusative or dative clitic. In fact, the speakers OVERACCEPT ungrammatical use instead of rejecting everything, which may be an indication of uncertainty. Therefore, they are familiar with the different forms of Portuguese clitics but some of them show optionality when faced with the valency or subcategorisation frame of the respective verb that has to be acquired along with its lexical entry. Since the verbs employed in the test items are common words, frequently used in speech, we do not think that the problem is the acquisition of the verbal valency per se, but lack 
Table 2. Employment of the right clitic form: mean, SD, statistical significance (Mann-Whitney U-test).

\begin{tabular}{|c|c|c|c|c|}
\hline & $\begin{array}{l}\text { monolingual speakers } \\
(n=18) \\
\text { mean }(\mathrm{SD})\end{array}$ & $\begin{array}{l}\text { heritage speakers } \\
(n=18) \\
\text { mean }(\mathrm{SD})\end{array}$ & $\begin{array}{l}\text { Mann-Whitney } \\
\text { U }\end{array}$ & $p$ \\
\hline $\begin{array}{l}\text { Type 1a: accusative clitic as dative } \\
\text { (ungrammatical) }\end{array}$ & $100(.00)$ & $70(35.15)$ & 72.00 & $<.001$ \\
\hline $\begin{array}{l}\text { Type } 1 \mathrm{~b} \text { : dative instead of accusative } \\
\text { (ungrammatical) }\end{array}$ & $100(.00)$ & $71.11(41.29)$ & 99.00 & $<.05$ \\
\hline
\end{tabular}

of confidence in their linguistic intuition. This lack of confidence is certainly related to reduced opportunities to use the HL. Transfer from their stronger language, German, can be excluded in these examples because the verbs used in the test govern the same case (dative or accusative) as in German.

The second condition had four sub-conditions: Type 2a) grammatical -no/-na (4a); Type $2 \mathrm{~b})$ ungrammatical $o /-a$ instead of $-n o /-n a(4 b)$; Type 2c) grammatical -lo/-la (4c) and Type 2d) ungrammatical $-o /-a$ instead of $-l o /-l a$ (4d).

(4) a. (O ladrão escondeu-se) mas os meninos

(the thief hides-himself) but the children

viram-no.

saw-him clitic $_{\text {. }}$

"The thief hides himself but the children saw him."

b. (O palhaço fugiu do circo),

(the clown escaped from-the circus)

*mas os meninos viram-o.

but the children saw-him clitic

"The clown escaped from the circus but the children saw him."

c. (A mãe não tem tempo para fazer um bolo), (the mother not has time to make a cake) mas eles querem fazê-lo.

but they want do-it $t_{\text {clitic }}$

"The mother doesn't have the time to make a cake, but they want to do it."

d. (A princesa hoje vem ao baile.) (the princess today comes to-the ball)

${ }^{*}$ Os convidados querem ver-a.

the guests want to see-her clitic $_{1}$

"Today the princess comes to the ball. The guests want to see her."

The use of allomorphic clitic forms seems to be the condition with the most expressive results. As shown by Table 3, the HSs are almost unable to judge correctly the employment of the ungrammatical form $-o /-a$ instead of the shaped form $-n o /-n a$.

The mean of accurate judgments is $11.11 \%$ in this group $(\mathrm{SD}=23.98)$. Individual results show that 14 out of 18 informants do not recognise the ungrammatical employment of $-o /-a$ in all five example sentences and that no HS scores correctly in all the sentences. The highest score is $80 \%$ (four out of five sentences), reached by only one participant.

This weak knowledge is confirmed by the judgments of the correct form -no/-na. The HSs only accept the correct form in $54.61 \%(\mathrm{SD}=24.62)$ of the given contexts. In fact they substitute the correct form by an incorrect one in $45.39 \%$ of all sentences.

Furthermore, it is interesting to note that HSs exhibit more difficulties with the use of the allomorphs -no/-na than with the forms -lo/-la. They score higher in the Type $2 \mathrm{c}$ and Type $2 \mathrm{a}$ conditions than in their counterparts, Type $2 a$ and Type $2 b$.

A Mann-Whitney U-test indicates that the HSs and the monolingual controls differ significantly in all four sub-conditions of Type 2 (see Table 3). However, it is possible to identify similar tendencies in both groups. Like the heritage bilinguals, the monolingual controls also perform lower in condition Type $2 b$, i.e. they reject the ungrammatical employment of $-o /-a$ instead of $-n o /-n a$ in only $82.22 \%$ of all contexts. In this case the standard deviation is about 29.01, which is indicative of some variation within this group. This fact suggests that morphological shape might also be a source of variation in native speech. Regarding the employment of shaped clitic forms, the native controls do not score $100 \%$ correctly in any condition.

We attribute the weaker performance of the HS group to the fact that they have received less formal instruction in EP and their restricted contact with written registers. Given that these morphologically deviant forms are taught at school, the low level of formal instruction might explain why the HSs show difficulties recognising the targetdeviant use of $-o /-a$ in contexts which require $-n o /-n a$ or $-l o /-l a$. On the other hand, alternative explanations cannot per se be disregarded because the majority of monolingual control speakers have only a basic level of education and the majority of the bilingual speakers had at least some instruction in Portuguese and learned to read and write the language to some extent. Nevertheless, as has been shown in a number of studies on heritage bilingualism, these 
Table 3. Morphological shape: mean, SD, statistical significance (Mann-Whitney U-test).

\begin{tabular}{|c|c|c|c|c|}
\hline & $\begin{array}{l}\text { monolingual speakers } \\
(n=18) \\
\text { mean (SD) }\end{array}$ & $\begin{array}{l}\text { heritage speakers } \\
(n=18) \\
\text { mean }(\mathrm{SD})\end{array}$ & $\begin{array}{l}\text { Mann-Whitney } \\
\text { U }\end{array}$ & $p$ \\
\hline Type 2a: -no/-na (grammatical) & $98.89(4.71)$ & $54.61(24.62)$ & 20.00 & $<.001$ \\
\hline $\begin{array}{l}\text { Type } 2 \mathrm{~b}:-o /-a \text { instead of }-n o /-n a \\
\quad \text { (ungrammatical) }\end{array}$ & $82.22(29.01)$ & $11.11(23.98)$ & 18.50 & $<.001$ \\
\hline Type 2c: -lo/-la (grammatical) & $94.44(11.49)$ & $76.67(24.01)$ & 89.50 & $<.05$ \\
\hline $\begin{array}{l}\text { Type } 2 \mathrm{~d}:-o /-a \text { instead of }-l o /-l a \\
\quad \text { (ungrammatical) }\end{array}$ & $97.78(6.47)$ & $51.11(42.41)$ & 61.00 & $<.001$ \\
\hline
\end{tabular}

speakers are less experienced with the written form of the language (Pires \& Rothman, 2009). The speakers in our study also seem to rely mainly on spoken language when judging the sentences containing the shaped clitic forms. Despite a general tendency to overaccept ungrammatical forms (Type $2 \mathrm{~b}$ and $2 \mathrm{~d}$ ), the phonological saliency of the differently shaped forms (nasal -no/-na versus lateral $-l$ ) could explain the discrepancy between Type $2 \mathrm{a} / \mathrm{b}$ and Type $2 \mathrm{c} / \mathrm{d}$, which to a lesser extent is also observable in the native speakers' judgments.

The third condition "strong pronouns in object position" with the two ungrammatical subconditions Type $3 a)$ dative pronouns ( $5 a$ ) and Type $3 b$ ) accusative pronouns (5b) tests cross-linguistic influence from German.

(5) a. (O Mario fez anos ontem.)

(the Mario did years yesterday)

*O João deu uma prenda a ele

the John gave a present to him strong

"Yesterday was Mario's birthday. John gave

him a present."

b. (O Francisco não estudou para o teste (the Francis not studied for the test de Matemática.) ${ }^{*} \mathrm{O}$ professor chumbou ele. of mathematics) the teacher failed-him strong "Francis didn't study for the maths exam. His teacher failed him."

Table 4 shows the results for the selection of strong pronouns in object position.

The first observation is related to the performance of the HSs in the sub-condition Type 3a: the use of strong dative pronouns instead of clitics. They reject the employment of the ungrammatical strong pronoun a ele instead of the clitic -lhe in only $32.94 \%$ (SD = 37.54 ) of all sentences. The rejection of ungrammatical strong pronouns instead of clitics is slightly higher for accusative pronouns $(52.78 \%$; SD $=37.54)$. Compared with the native control group, a Mann-Whitney U-test shows significant differences between the groups in both conditions $(U=34.50, p=.000$, for Type $3 \mathrm{a}$, and $U=$ $27.00, p=.000$ for Type $3 b)$.

Again, the values of the standard deviation reveal considerable variation within the group of HSs. In fact, only one participant scores $100 \%$ correctly in both conditions; four participants judge $100 \%$ in one of the two conditions correctly; two participants do not recognise the ungrammaticality of the use of strong pronouns at all (neither the dative nor the accusative), while six participants do not recognise ungrammatical strong pronouns in the subcondition "dative", but give correct judgments in the subcondition "accusative". Curiously, two of these informants achieve $100 \%$ proficiency in the condition "accusative" and $0 \%$ proficiency when the strong pronoun is a dative.

Interestingly, the monolingual controls also perform differently in the two sub-conditions. They do not accept accusative strong pronouns in clitic position at all, reaching $100 \%$ rejection, but they show some variation with respect to the employment of dative strong pronouns instead of the dative clitic -lhe ( mean $=94.44 \%, \mathrm{SD}=9.22$ ).

Here, two observations need explanation: 1) the HSs' judgments again clearly deviate from those of the native speakers; and 2) there is a tendency to accept strong accusative pronouns in object position to a lesser extent than strong dative pronouns. One explanation for the first observation could be transfer from the stronger language. Because German only has strong pronominal forms, the HSs could also accept isolated strong object pronouns in Portuguese. However, if cross-linguistic influence were the only factor, we would not expect differences between accusative and dative forms. Twelve informants show a tendency to accept more dative strong pronouns than accusative, five of them only accepting the omission of the clitic in the dative condition (they reject 4-5 of the accusative examples).

In our view, this asymmetry (observation 2) can be explained on the basis of universal linguistic tendencies, because it also shines through the results of the monolingual controls. In principle, there are two 
Table 4. Strong pronouns in object position: mean, SD, statistical significance (Mann-Whitney U-test).

\begin{tabular}{lllll}
\hline \hline & $\begin{array}{l}\text { monolingual speakers } \\
(n=18) \\
\text { mean }(\mathrm{SD})\end{array}$ & $\begin{array}{l}\text { heritage speakers } \\
(n=18) \\
\text { mean }(\mathrm{SD})\end{array}$ & $\begin{array}{ll}\text { Mann-Whitney } \\
\mathrm{U}\end{array}$ & $p$ \\
\hline Type 3a: dative (ungrammatical) & $94.44(9.22)$ & $32.94(37.54)$ & 34.50 & $<.001$ \\
Type 3b: accusative (ungrammatical) & $100(.000)$ & $52.78(37.54)$ & 27.00 & $<.001$ \\
\hline \hline
\end{tabular}

possible explanations. First, strong pronouns are generally interpreted as animate (Cardinaletti \& Starke, 1999) and datives have a strong tendency to be animate. In fact, in our test a sentence with an inanimate accusative object (Os brinquedos eram da Loja dos Chineses. Os meninos destruiram eles. "The toys were from the Chinese store. The kids destroyed them.") is accepted less by the speakers (only by eight) than the examples with animate referents (accepted by 12-15). However, the data do not allow us to verify the hypothesis because we have only one sentence with an inanimate referent.

A second explanation may be derived from studies that assume a different analysis of dative and accusative clitics. Bleam (1999) argues that accusative clitics are determiners and dative clitics are inflections. Déchaine and Wiltschko (2002) propose that accusatives are Dclitics which trigger semantic effects, whereas datives are phi-clitics and serve as pure syntactic markers. If we interpret the use of a strong pronoun in object position as signalling omission of the corresponding clitic pronoun, the omission of accusative clitics is accepted to a lesser extent because of their semantic load. This is reminiscent of Andersen's (1982) claim that morphemes with high functional load will be maintained longer in language attrition situations. We conclude that the asymmetry between accusative and dative strong pronouns in object position relates to universal linguistic tendencies that are also visible in the judgments of the native controls and that it is predictable from the perspective of language attrition and language contact.

The condition "topicalisation" relates, among other things, to the syntax-discourse interface. It is divided into four sub conditions: grammatical topicalisation with a resumptive accusative (Type 4a; 6a) and dative clitic (Type $4 b ; 6 b$ ), and grammatical topicalisation without a resumptive accusative (Type 4c; 6c) and dative clitic (Type 4d; 6d).

(6) a. (Não gosto muito de ler romances,) mas (not like much PRÄP read novels) but estes livros, li-os com grande prazer. these books read-them clitic $_{\text {with }}$ great pleasure "I don't like reading novels very much, but I read these books with great pleasure." b. (A Susana ofereceu prendas a toda a gente,) (the Susan offered presents to all the people) mas aos irmãos, deu-lhes dinheiro. but to-the brothers gave-them clitic $_{\text {money }}$ "Susan offered presents to everybody, but to her brothers she gave money."

c. (A Maria não gosta de ler,) mas (the Mary not likes to read) but esse livro leu com muito interesse. this book read with great interest "Mary doesn't like to read, but this book she read with great interest."

d. (A direcção ofereceu prendas a toda a (the management offered presents to all the gente.) Aos colaboradores mais antigos, people) to-the workers most long-standing deu um relógio fantástico gave a watch fantastic "The management offered presents to everybody. To the most long-standing workers they gave a fantastic watch."

The results for these conditions are given in Table 5 .

The HSs show a slightly poorer performance in these conditions. The monolingual speakers accept topicalisation with accusative clitics in $97.78 \%$ of all contexts $(\mathrm{SD}=6.47)$ and topicalisation with dative clitics in $91.11 \%(\mathrm{SD}=24.94)$ of the items. In the group of HSs the mean level of acceptance is lower but the rates are similar for both clitic types: $86.67 \%(\mathrm{SD}=$ $16.80)$ for accusatives and 85.56 $(\mathrm{SD}=22.55)$ for datives. Both groups show higher rates of acceptance for the constructions without a dative clitic (controls: $88.89 \%$; $\mathrm{SD}=17.11$; HSs: $80 \%$; $\mathrm{SD}=24.73$ ) compared to topicalisation without an accusative clitic (controls: $64.44 \%(\mathrm{SD}=28.74)$; HSs $58.89 \%(\mathrm{SD}=29.48))$. A Mann-Whitney U-test shows no significant differences between native controls and HSs in conditions Type 4b, Type $4 \mathrm{c}$ and Type $4 \mathrm{~d}$ (see Table 5). Both groups only differ statistically for condition Type $4 \mathrm{a}(U=104.00, p=0.20)$.

Although the heritage bilinguals score slightly lower than the monolingual controls, they display exactly the same tendencies with respect to acceptability in the 
Table 5. Topicalisation: mean, SD, statistical significance (Mann-Whitney U-test).

\begin{tabular}{|c|c|c|c|c|}
\hline & $\begin{array}{l}\text { monolingual speakers } \\
(n=18) \\
\text { mean }(\mathrm{SD})\end{array}$ & $\begin{array}{l}\text { heritage speakers } \\
(n=18) \\
\text { mean (SD) }\end{array}$ & $\begin{array}{l}\text { Mann-Whitney } \\
\text { U }\end{array}$ & $p$ \\
\hline $\begin{array}{l}\text { Type 4a: with resumptive accusative clitic } \\
\text { (grammatical) }\end{array}$ & $97.78(6.47)$ & $86.67(16.80)$ & 104.00 & $<0.05$ \\
\hline $\begin{array}{l}\text { Type 4b: with resumptive dative clitic } \\
\text { (grammatical) }\end{array}$ & $91.11(24.94)$ & $85.56(22.55)$ & 128.50 & .179 \\
\hline $\begin{array}{l}\text { Type 4c: without resumptive accusative } \\
\text { clitic (grammatical) }\end{array}$ & $64.44(28.74)$ & $58.89(29.48)$ & 144.50 & .571 \\
\hline $\begin{array}{l}\text { Type 4d: without resumptive dative clitic } \\
\text { (grammatical) }\end{array}$ & $88.89(17.11)$ & $80(24.73)$ & 129,50 & .257 \\
\hline
\end{tabular}

different subtypes of sentence in the experiment. In general, both groups reveal higher rates of acceptability of topicalised constructions with the resumptive clitic pronoun than without it. This proves that cross-linguistic influence cannot be at play here, because one would expect exactly the opposite. If we look at the case of the object, no difference is found in the topicalisation of direct and indirect objects with resumptive dative or accusative pronouns. The overall results show that constructions at the syntax-discourse interface are not in themselves problematic for the speakers. The HSs perform better and show less deviation from the native controls in this condition than in the previous conditions. Interestingly, both groups manifest the same tendency to prefer topicalisation of an indirect object without a resumptive clitic to a direct object without a resumptive clitic. We think that this asymmetry relates to the findings from the previous condition. As argued by Raposo (1986), topicalisation constructions without a resumptive clitic involve an empty clitic in object position. He assumes that the topic is base-generated in situ and that an empty operator binds the empty category in object position. Raposo's analysis can be extended to constructions with a strong pronoun alone ( $5 \mathrm{a}$ vs. $5 \mathrm{~b}$ ). An empty clitic is therefore more easily accepted with datives/indirect objects than with accusatives/direct objects.

According to Raposo (1986), null objects in EP are restricted to unembedded contexts. This restriction is reflected in the lower acceptability of topicalisation structures representing the empty category in an embedded clause (7a) than cases where the empty element occurs in an independent sentence (7b):
(7) a. Piscina
não sabia que tinha .
Swimming pool not knew that has _
"A swimming pool, I didn't know that there was one."
(Corpus Português Fundamental, G1883)

b. (Já sei qual é o livro que procuras.) already know which is the book that look for Esse livro, o Luis comprou _ para a Maria. this book the Luis bought for the Mary "I know which book you are looking for. This book Luis bought for Mary."

Example (7a), which is cited in Duarte (1987: 74), was presented as a context-embedded test sentence. Only three out of 18 HSs and only eight monolinguals accepted it. Sentence (7b), on the other hand, was accepted by 12 out of $18 \mathrm{HSs}$ and 13 out of 18 monolingual controls. ${ }^{5}$

The different 'placement' options test syntactic knowledge. They divide into eight sub-conditions: Type 5a) grammatical postverbal position with subjects, Type 5b) ungrammatical preverbal position with subjects, Type 5c) grammatical preverbal position with negation, Type 5d) ungrammatical postverbal position with negation, Type 5e) grammatical preverbal position in subordinate clauses, Type $5 \mathrm{f}$ ) ungrammatical postverbal position in subordinate clauses, Type $5 \mathrm{~g}$ ) grammatical postverbal position and Type $5 \mathrm{~h}$ ) ungrammatical preverbal position with non-finite verbs. Since the alternation between enclisis and proclisis is triggered by multiple conditions, we will discuss the results for Type 5 by going through the different sub-conditions separately.

Table 6 displays the accuracy judgments for main clauses with a preverbal subject, a context which requires enclisis (cf. 8a-b).

\footnotetext{
5 Of course, sentence (7a) is also infelicitous because the topic piscina "swimming pool" is an indefinite and non-specific noun phrase. An anonymous reviewer suggested that its low acceptability might be related to weight effects, as described in Frota and Vigário (2001), instead of its embedded structure. Since the discussion of this topic goes beyond the aim of our study, we will not investigate it further. We think several conjunct factors may contribute to its high rejection rate.
} 
Table 6. Placement with finite verbs: mean, SD, statistical significance (Mann-Whitney U-test).

\begin{tabular}{lllll}
\hline \hline & $\begin{array}{l}\text { monolingual speakers } \\
(n=18) \\
\text { mean }(\mathrm{SD})\end{array}$ & $\begin{array}{l}\text { heritage speakers } \\
(n=18) \\
\text { mean }(\mathrm{SD})\end{array}$ & $\begin{array}{l}\text { Mann-Whitney } \\
\mathrm{U}\end{array}$ & $p$ \\
\hline $\begin{array}{l}\text { Type 5a: postverbal position with } \\
\text { subjects (grammatical) }\end{array}$ & $100(.000)$ & $87.78(22.90)$ & 117.00 & $<.05$ \\
$\begin{array}{l}\text { Type } 5 \text { b: preverbal position with subjects } \\
\text { (ungrammatical) }\end{array}$ & $95.56(10.97)$ & $62.22(34.22)$ & 69.50 & $<.001$ \\
\hline \hline
\end{tabular}

(8) a. (O meu pai não gostava nada de estudar.) (the my father not liked nothing to study) O professor chumbou-o várias vezes. the teacher failed-him clitic $_{\text {several times }}$ "My father didn't like to study at all. His teacher failed him several times."

b. *(O Carlos não estudou, $)$ por isso, (the Carlos not studied) therefore o professor o chumbou. the teacher him clitic $_{\text {failed }}$

"Carlos didn't study; therefore the teacher failed him."

As mentioned in section 3, enclisis seems to be the less problematic word order pattern in EP. EP children overgeneralise enclisis in the first stages of acquisition. Adult EP speakers also show some variation and sometimes produce enclisis instead of proclisis, but not the inverse.

So, as expected, all monolingual speakers judged the grammatical enclisis word order correctly $(100 \%)$. The performance of the HSs is slightly lower (mean 87.78, $\mathrm{SD}=22.90)$. In the case of the ungrammatical preverbal clitic position, the monolingual speakers recognised the ungrammaticality in $95.56 \%(\mathrm{SD}=10.97)$ of all contexts. The mean level of accuracy is significantly lower in the HS group $(62.22 \%, \mathrm{SD}=34.22)$. This means that the heritage bilinguals accept ungrammatical proclisis constructions in main clauses which do not trigger the preverbal clitic position. This deviant performance by the HSs clearly differentiates them from the monolingual controls. Again it is worth taking a closer look at the individual results of the bilingual informants for this sub-condition. The individual results show that nine informants $(50 \%$ of the sample) score accurately in $80-100 \%$ of all contexts, while the other nine perform very poorly. It appears that half of the participants show native-like performance in this condition, while the other half deviate from native performance.

As discussed above, several conditions trigger the preverbal clitic position. For this test we selected two: negation and subordinate clauses with finite verbs (9a-d). Costa et al. (in press) have shown that negation is the first context in which EP children produce proclisis. Flores and Barbosa (2012) further found that HSs produce more proclisis in negation than in other contexts.

(9) a. (O pai do Francisco foi à (the father of-the Francis was at-the escola reclamar.)

school to complain)

Então o professor não o chumbou.

so the teacher not him $_{\text {clitic }}$ failed

"Francis' father was at the school to complain.

Therefore, the teacher didn't fail him."

b. ${ }^{*}(\mathrm{O}$ Pedro estudou muito $)$ e no final (the Pedro studied a lot) and in-the end do ano o professor não chumbou-o. of-the year the teacher not failed-him clitic $_{\text {- }}$ "Pedro studied a lot and at the end of the school year his teacher didn't fail him."

c. $(\mathrm{O}$ avô do Manel desapareceu (the grandfather of-the Manel disappeared há muitos anos.)

many years ago)

$\mathrm{O}$ seu pai acha que o viu ontem. the his father thinks that him clitic $_{\text {saw yesterday }}$ "Manel's grandfather disappeared many years ago. His father thinks that he saw him yesterday."

d. *(O Alberto emigrou para França, $)$ (the Albert emigrated to France)

mas a Maria afirma que viu-o ontem but the Mary affirms that saw-him clitic $_{\text {yesterday }}$ em Lisboa.

in Lisbon

"Albert emigrated to France but Mary says that she saw him yesterday in Lisbon."

The accuracy rates of both groups for both sub-conditions are given in Table 7.

The data reveals 100\% accuracy judging grammatical proclisis order with negation in the monolingual control group, but some variation in judging ungrammatical 
Table 7. Preverbal clitic placement (with negation and in subordinate clauses): mean, SD, statistical significance (Mann-Whitney U-test).

\begin{tabular}{|c|c|c|c|c|}
\hline & $\begin{array}{l}\text { monolingual speakers } \\
(n=18) \\
\text { mean }(\mathrm{SD})\end{array}$ & $\begin{array}{l}\text { heritage speakers } \\
(n=18) \\
\text { mean }(\mathrm{SD})\end{array}$ & $\begin{array}{l}\text { Mann-Whitney } \\
\text { U }\end{array}$ & $p$ \\
\hline $\begin{array}{l}\text { Type 5c: preverbal position with negation } \\
\text { (grammatical) }\end{array}$ & $100(.00)$ & $89.22(19.20)$ & 117.00 & $<.05$ \\
\hline $\begin{array}{l}\text { Type 5d: postverbal position with } \\
\text { negation (ungrammatical) }\end{array}$ & $95.56(8.56)$ & $67.78(28.40)$ & 42.00 & $<.001$ \\
\hline $\begin{array}{l}\text { Type 5e: preverbal position with } \\
\text { subordinate clauses (grammatical) }\end{array}$ & $96.67(7,67)$ & $86.67(16.80)$ & 111.000 & 0.05 \\
\hline $\begin{array}{l}\text { Type 5f: postverbal position with } \\
\text { subordinate clauses (ungrammatical) }\end{array}$ & $80.00(20.58)$ & $52.50(27.24)$ & 70.500 & $<.05$ \\
\hline
\end{tabular}

enclisis with negation in the same group. This means that monolingual native speakers residually accept postverbal clitic position in negative constructions (mean $=95.56$, $\mathrm{SD}=8.56$ ). The same tendency can be observed in the HS group. The heritage bilinguals accept grammatical proclisis order with negation in $89.22 \%(\mathrm{SD}=19.20)$ of all contexts, but they reject ungrammatical enclisis with negation only at a mean rate of $67.78 \%(\mathrm{SD}=28.40)$. A Mann-Whitney U-test confirms that both groups differ significantly in both sub-conditions (see Table 7) which involve negative sentences. As discussed above, the difference between the grammatical and the ungrammatical items is related to a general tendency for the acceptance of ungrammatical conditions in grammaticality judgment tasks, which is observed in both groups.

If we compare the scores for accuracy in the subconditions with clitic placement in contexts of negation with the second sentence type, i.e. clitic placement in subordinate clauses (Types $5 \mathrm{e}$ and $5 \mathrm{f}$ ), we find differences between the conditions that require proclisis. Negation seems to be less susceptible to variation than embedded sentences. The monolingual controls reject ungrammatical enclisis construction with subordinate clauses in only $80 \%$ of the sentences $(\mathrm{SD}=20.58)$, against the $95.56 \%$ of rejection for enclisis with negation. In the HS group the rate of rejection is significantly lower. Ungrammatical enclisis constructions with subordinate clauses are only rejected in $52.50 \%$ of the given sentences $(\mathrm{SD}=27.24)$. Both groups differ significantly in condition Type $5 \mathrm{f}(U=70.500, p<=.05)$. With Type $5 \mathrm{e}$ the differences between both groups are less significant ( $U=111.00, p=.046)$, though the HSs perform less well than the controls.

This asymmetry between the negation and subordinate clauses as triggers for proclisis is also demonstrated in other studies (Costa et al., in press; Flores \& Barbosa, 2012) and can be explained as a result of the acquisition process. In L1 acquisition, proclisis with negation is acquired earlier and with less variation, whereas proclisis with subordinate clauses is a more delayed and complex acquisition task (involving the acquisition of the $\mathrm{C}$-system and of complex sentences) (Costa et al., in press). In addition, in spoken Portuguese, enclisis occurs in some types of embedded clauses (with bridge verbs like dizer'to say'). These are the contexts of embedded enclisis which are also accepted by some of the monolingual controls and the HSs.

The last sub-context relates to enclitic placement with non-finite verbs $(10 \mathrm{a}-\mathrm{b})$. The scores of accuracy of both groups are given in Table 8 .

(10) a. (O nosso cão terá de ficar com os meus (the our dog will-have to stay with the my pais.)

parents)

E impossível levá-lo para o hotel.

is impossible take-him clitic $_{\text {to }}$ the hotel

"Our dog will have to stay with my parents.

It is impossible to take him to the hotel."

b. (Estás mesmo mal-disposta.) *É impossível te (are really bad-tempered) is impossible you aturar.

to put-up-with

"You are really bad-tempered. It's impossible to put up with you."

As in the results for the previous conditions, both groups are better at judging grammatical constructions than ungrammatical ones. The monolingual controls accept grammatical enclisis order with non-finite verbs in all contexts (100\% acceptance), while the HSs accept these grammatical constructions in $89.22 \%(\mathrm{SD}=19.20)$ of the given contexts. A Mann-Whitney test shows significant differences between both groups regarding this clause type $(U=117.00, p<.05)$. 
Table 8. Clitic placement with non-finite verbs: mean, SD, statistical significance (Mann-Whitney U-test).

\begin{tabular}{lllll}
\hline \hline & $\begin{array}{l}\text { monolingual speakers } \\
(n=18) \\
\text { mean (SD) }\end{array}$ & $\begin{array}{l}\text { heritage speakers } \\
(n=18) \\
\text { mean (SD) }\end{array}$ & $\begin{array}{l}\text { Mann-Whitney } \\
\mathrm{U}\end{array}$ & $P$ \\
\hline $\begin{array}{l}\text { Type 5g: postverbal position } \\
\text { (grammatical) }\end{array}$ & $100(.00)$ & $89.22(19.20)$ & 117.00 & $<.05$ \\
$\begin{array}{l}\text { Type 5h: preverbal position } \\
\text { (ungrammatical) }\end{array}$ & $93.33(11.88)$ & $42.22(32.82)$ & 55.00 & $<.001$ \\
\hline \hline
\end{tabular}

The results are even more striking for the ungrammatical construction in this sub-condition. The heritage bilinguals only reject ungrammatical proclisis order with non-finite verbs in $42.22 \%(\mathrm{SD}=32.82)$ of all contexts. This is a very low rate of accuracy. A MannWhitney test confirms significant differences between both groups regarding this subtype $(U=55.00, p<.001)$.

As already shown with respect to subtype $5 \mathrm{~b}-$ ungrammatical proclisis with subjects - HSs show a significantly lower rate of rejection of this word order than monolingual controls.

Comparing the individual results of the HSs in both sub-conditions we see that the participants who accept ungrammatical proclisis in finite sentences are mostly the same individuals who accept proclisis with non-finite verbs. This suggests that those speakers' judgments are not random but the result of competence differences. On the other hand, the HSs who show accurate judgments in one sub-condition also demonstrate high rates of accuracy in the other. This means that some HSs equal monolingual speakers in their linguistic knowledge, while others seem to systematically diverge from the monolingual native speakers' competence, at least with respect to preverbal clitic placement in contexts of enclisis.

Interestingly, the HSs who have problems with clitic placement show deficiencies in ungrammatical proclitic as well as in enclitic contexts. The participants who do not achieve $80 \%$ accuracy in both contexts where proclisis is ungrammatical also score poorly (i.e. less than $80 \%$ accurate judgments) in the contexts where enclisis is ungrammatical. This contradicts the tendency observed in monolingual acquisition and in spoken registers of EP, where enclisis is overgeneralised. This may be the result of deficient knowledge or chance performance when speakers are not sure of their judgment.

The last context which was tested is clitic placement in restructuring contexts. Three subtypes were tested: Type 6a) grammatical placement between auxiliary and main verb (11a), Type 6b) grammatical placement to the right of the main verb (11b) and Type 6c) ungrammatical proclisis to the left of the auxiliary (11c).
(11) a. (O livro esgotou esta semana.) Os alunos (the book was sold out this week) the students podem-no comprar na semana que vem.

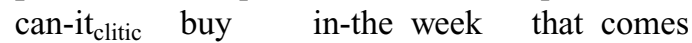
"The book was sold out this week. The students can buy it next week."

b. (O livro do Manuel está quase terminado.) (the book of-the Manuel is almost finished) João pode comprá-lo na semana que vem.

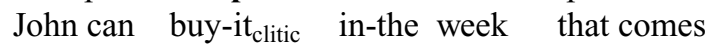
"Manuel's book is almost finished. John can buy it next week."

c. (Não consegui comprar o bilhete hoje.) (not managed to buy the ticket today) *O João o pode comprar amanhã.

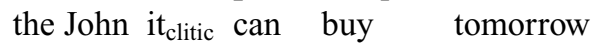
"I didn't manage to buy the ticket today. John can buy it tomorrow."

The accuracy scores are given in Table 9.

In this condition, the monolingual controls, as expected, accept grammatical enclisis with the main verb in $96.67 \%$ of the cases (Type 6b) and reject ungrammatical placement of the clitic to the left of the auxiliary (Type $6 c$ ) at a mean rate of $97.78 \%$. Unexpectedly, however, the other grammatical option, placement of the clitic between auxiliary and main verb (11a), is only accepted in $59.44 \%$ of cases. As already mentioned in section 4 , monolingual speakers may reject this option because they are taught to do so in school and/or because in their northern dialect enclisis to the (semi-)auxiliary is less frequent than enclisis to the main verb. Therefore, the HSs may show more target-like performance than the monolingual controls because of their more limited schooling in Portuguese and the fact that their knowledge of the language is more strongly based on the spoken register.

The heritage bilinguals do not reach the same rate of accuracy in condition Type $6 b(79.72 \%)$ and $6 c$ (71.83\%) as the monolingual controls, but in principle they show knowledge of the different placement options. 
Table 9. Placement in restructuring contexts: mean, SD, statistical significance (Mann-Whitney U-test).

\begin{tabular}{lllll}
\hline \hline & $\begin{array}{l}\text { monolingual speakers } \\
(n=18) \\
\text { mean (SD) }\end{array}$ & $\begin{array}{l}\text { heritage speakers } \\
(n=18) \\
\text { mean (SD) }\end{array}$ & $\begin{array}{l}\text { Mann-Whitney } \\
\mathrm{U}\end{array}$ & 118.500 \\
\hline $\begin{array}{l}\text { Type 6a: between auxiliary and main verb } \\
\text { (grammatical) }\end{array}$ & $59.44(32.88)$ & $74.44(33.47)$ & 80.500 & $<.154$ \\
$\begin{array}{l}\text { Type 6b: to the right of the main verb } \\
\text { (grammatical) }\end{array}$ & $96.67(10.29)$ & $79.72(21.73)$ & 72.500 & $=.001$ \\
$\begin{array}{l}\text { Type 6c: to the left of the auxiliary } \\
\text { (ungrammatical) }\end{array}$ & $97.78(9.43)$ & $71.83(32.73)$ & & \\
\hline \hline
\end{tabular}

In particular, no preference for the placement of the clitic between auxiliary and main verb is found as would be expected if their judgments were influenced by their stronger language, German. We therefore conclude that cross-linguistic influence is not decisive for the HSs' judgments in this case.

Finally, some more should be said about individual variation in the HS group. The results have shown that, overall, their morphosyntactic knowledge is characterised by a high degree of variation. While some speakers display almost native-like knowledge in some sub-conditions, others deviate significantly from the monolingual controls. Furthermore, as shown above, there appears to be some consistency in the results related to clitic placement: the speakers who have difficulties knowing which contexts require preverbal placement are mostly those who have difficulties in judging ungrammatical enclisis. However, it is not possible to say that these speakers are also the same as those who score poorly in the other sub-conditions. In fact, some speakers show high rates of accuracy in one sub-condition, but score poorly in others, which means we cannot say that some participants in our experimental group are low-proficiency speakers overall, while others have a high level of proficiency in EP. What we can say is that the HSs' judgments show gaps, but that these gaps are not the same for all participants.

\section{Discussion}

In this section we will relate the results presented in the preceding section to the hypotheses we established in section 4.

According to hypothesis I, if age of onset of acquisition were the decisive factor determining the acquisition of clitics in EP, we would expect no qualitative differences between monolingual speakers and heritage bilinguals. However, we do find such differences between the groups in almost all conditions. The mean level of accuracy is about $91.96 \%$ in the control group and only about $67.02 \%$ in the group of HSs. In addition, the amount of intergroup variation differs significantly between the two groups. Therefore, we conclude that the age of onset of acquisition is not the only decisive factor determining the speakers' knowledge of clitics. Although both groups have acquired Portuguese as their L1 from birth, they clearly differ in their linguistic knowledge. The crucial question is, therefore, in which domains of their knowledge do heritage bilinguals differ from native monolinguals and which factors play a decisive role?

The first factor we will discuss is the role of formal education and experience with the formal register of the language (hypothesis IIa), which is confirmed by the results presented in section 6. It is reflected, for example, in the weak performance of the HSs with respect to the contracted forms of the clitic. They were only able to reject ungrammatical non-contracted forms in $11.11 \%$ of the cases (monolinguals in $82.22 \%$ ) and even failed to recognise the grammatical constructions with contracted forms [54.61\% accuracy (bilinguals) vs. $98.89 \%$ (monolinguals)]. In many cases the HSs even "corrected" grammatical examples of contracted forms into ungrammatical non-contracted forms. Their limited access to formal education and written registers may also explain their lower metalinguistic awareness. Their lower metalinguistic abilities are reflected in their tendency to overaccept ungrammatical constructions. In all conditions, the HSs score less accurately in ungrammatical items than in grammatical ones, which shows that in situations of uncertainty they tend to accept ungrammatical constructions.

Interestingly, and as we would expect if we ascribe the differences to formal education, we found that intragroup variation is very high. Some HSs performed just like monolinguals and others very poorly. Although the HSs did all have access to formal registers to some extent, the outcome was expected to be variable because it also depends on non-linguistic factors that cannot be controlled for in the tests (e.g. the personal motivation of the speaker or how frequently she/he attended the course). 
In one case, the lack of formal education turned out to be an advantage for the HSs. In contrast to monolinguals who rejected grammatical placement of the clitic between auxiliary and infinitival verb in contexts of clitic climbing (59.44\% accuracy), the HSs performed better at recognising the grammaticality of the examples (74.44\%). We conclude that the lack of formal education and the HSs' lesser experience with the formal register are decisive factors for the observed differences between the two groups.

Hypothesis II.b concerns the change in the input after the ages of three to six. If this factor plays a role, we would expect properties that are acquired later to be more problematic than those that are acquired in early childhood.

Given the fact that clitic placement is a complex acquisition task and acquired relatively late in first language acquisition (cf. section 3), we hypothesised that the HSs could show problems with the contexts of proclisis and overgeneralise enclisis to contexts that require proclisis, which is found in the early phases of first language acquisition. However, this expectation was not confirmed, though the HSs' judgments did show some deviations from those of the monolinguals. In principle, the HSs were able to recognise the grammaticality of proclitic placement in contexts of negation and subordination and of enclitic placement with subjects and non-finite verbs. These findings match Flores and Barbosas's (2012) observation that HSs take longer to acquire clitic placement, but they can achieve full knowledge of this property. Although the HSs included in the present study encountered difficulties rejecting the ungrammatical placement options, they did not display a tendency to accept ungrammatical enclisis more often than ungrammatical proclisis. In addition, a comparison of the individual results of the HSs showed that the participants who accept ungrammatical proclisis in finite sentences are almost the same individuals who accept ungrammatical proclisis with non-finite verbs. Furthermore, the same participants tend to exhibit difficulties with clitic placement in contexts which require enclisis. This suggests that some speakers do indeed have a deviant knowledge of these word order constraints. We conclude that reduced input alone cannot explain the differences between the two groups of participants.

In our study, cross-linguistic influence does not seem to be a relevant factor in explaining the performance differences between the native monolinguals and the heritage bilinguals (hypothesis II.c). This is, first and foremost, because heritage bilinguals do not show a tendency to use the German placement option in contexts of optionality. They attained the same rate of accuracy with respect to the two grammatical conditions of clitic climbing (between auxiliary and main verb (as in German) $74.44 \%$ and to the right of the main verb (ungrammatical in German) $79.72 \%$ ).
Secondly, it was observed that constructions involving the syntax-discourse interface (hypothesis II.d) are not more problematic than other constructions. On the contrary, the HSs did not show noticeable difficulties in accepting clitic left dislocation structures with or without resumptives.

Thirdly, not all the HSs generally overaccepted sentences with strong pronouns. Although they deviated significantly from the monolingual speakers, we observed that two thirds of the bilingual informants had a tendency to overaccept strong dative pronouns in object position, but the same was not true of accusative strong pronouns. We attributed this asymmetry to universal linguistic tendencies. We conclude that although cross-linguistic influence may strengthen certain tendencies it is not the decisive factor that causes them.

Finally, it should be noted that the structures where the heritage bilinguals showed weaker performance are exactly those in which the monolingual native speakers scored less than $100 \%$ accuracy. This indicates that HSs perform less accurately in domains which also seem to be the locus of some variation in current EP (e.g. the use of strong dative pronouns instead of clitics). The weaker performance of the HSs in these domains may be the result of exposure to less consistent input. Monolingual speakers are also exposed to variation in colloquial speech, but their contact with other sources of input (more formal and written input) tends to counterbalance the development of linguistic variation. The lack of exposure to these countervailing sources in HSs may explain our findings. Furthermore, in the case of HL acquisition, the first generation of migrants may also function as the locus of variation. As discussed in section 2, it cannot be ruled out that the L1 of first generation migrants is subject to slight attrition, thus contributing to input inconsistency.

\section{Conclusion}

To sum up, although we observe differences in the morphosyntactic knowledge of clitics between native monolingual speakers and heritage bilinguals, we think that reduced input after the age of three to six is not the only factor influencing HL development. One important factor is the lesser experience of the HSs with the formal register, especially in written forms of language. Therefore, in performing the test they have to rely mainly on the spoken register. This leads not only to the differences described above, but also explains a general tendency to overaccept ungrammatical constructions instead of correcting them, which might signal lower metalinguistic abilities. It should be noted, however, that the same speakers sometimes show a very high level of performance in the grammatical conditions. In addition, their reliance on the vernacular results in intralinguistic developments, which in turn foster a 
linguistic change that is already present in the language, as we have observed with respect to clitic omissions. We conclude that although the linguistic knowledge of the heritage bilinguals investigated in this study differs from that of monolinguals, it is not "deficient" but "different" and "innovative", because it is primarily based on the spoken variety of the language and because it promotes linguistic changes which are inherent in the speech of native monolinguals. Cross-linguistic influence seems to play a less important role than generally assumed.

\section{References}

Andersen, R. W. (1982). Determining the linguistic attributes of language attrition. In R. D. Lambert \& B. F. Freed (eds.), The loss of language skills, pp. 83-118. Rowley, MA: Newbury House.

Au, T., Knightly, L., Jun, S., \& Oh, J. (2002). Overhearing a language during childhood. Psychological Science, 13, 238-243.

Barbosa, P. (1996). Clitic placement in European Portuguese and the position of subjects. In A. Halpern \& A. Zwicky (eds.), Approaching second: Second position clitics and related phenomena, pp. 1-40. Stanford, CA: CSLI Publications.

Barbosa, P. (2008). Clíticos, deslocação local e linearização cíclica. Diacrítica. Série Ciências da Linguagem, 22, 131156.

Bleam, T. (1999). Leísta Spanish and the syntax of clitic doubling. Ph.D. dissertation, University of Delaware.

Bolger, P. A., \& Zapata, G. C. (2011). Psycholinguistic approaches to language processing in heritage speakers. Heritage Language Journal, 8, 1-29.

Cardinaletti, A., \& Starke, M. (1999). The typology of structural deficiency: A case study of the three classes of pronouns. In H. Riemsdijk (ed.), Clitics in the languages of Europe, pp. 145-123. Berlin: Mouton de Gruyter.

Costa, J., \& Lobo, M. (2007). Clitic omission, null objects or both in the acquisition of European Portuguese? In S. Baauw, F. Drijkoningen, \& M. Pinto (eds.), Romance languages and linguistic theory 2005, pp. 5971. Amsterdam/Philadelphia: John Benjamins.

Costa, J., \& Lobo, M. (2011). Objeto nulo na aquisição do português europeu: Pro ou variável? In A. Costa, I. Falé \& P. Barbosa (eds.), Textos Selecionados do XXVI Encontro da Associação Portuguesa de Linguística, pp. 197-207. Lisbon: APL.

Costa, J., Fiéis, A., \& Lobo, M. (in press). Input variability and late acquisition: Clitic misplacement in European Portuguese. Lingua.

Déchaine, R.-M., \& Wiltschko, M. (2002). Decomposing pronouns. Linguistic Inquiry, 33, 409-422.

Duarte, I. (1987). A Construção de Topicalização na Gramática do Português: Regência, Ligação e Condições sobre Movimento. Ph.D. dissertation, University of Lisbon.

Duarte, I. (1996). A topicalização em português europeu: Uma análise comparativa. In I. Duarte \& I. Leiria (eds.), Actas do congresso internacional sobre o português, pp. 327-358 Lisbon: APL/Colibri.
Duarte, I., Matos, G., \& Faria, I. H. (1995). Specificity of European Portuguese clitics in Romance. In I. H. Faria \& M. J. Freitas (eds.), Studies on the acquisition of Portuguese, pp. 129-154. Lisbon: APL/Colibri.

Erlam, R. (2013). Effects of instruction on learners' acquisition of metalinguistic knowledge. In K. Roehr \& G. A. GanemGutierre (eds.), The metalinguistic dimension in instructed second language learning, pp.71-94. New York/London: Bloomsbury.

Fernández Soriano, O. (1999). El pronombre personal. Formas y distribuciones. Pronombres átonos y tónicos. In I. Bosque \& V. Delmonte (eds.), Gramática descriptiva de la lengua española, 1. Sintaxis básica de las clases de palabras, pp. 1209-1273. Madrid: Espasa.

Flores, C. (2010). The effect of age on language attrition: Evidence from bilingual returnees. Bilingualism: Language and Cognition, 13, 533-546.

Flores, C. (2012). Differential effects of language attrition in the domains of verb placement and object expression. Bilingualism: Language and Cognition, 15, 550567.

Flores, C., \& Barbosa, P. (2012). When reduced input leads to delayed acquisition: A study on the acquisition of clitic placement by Portuguese heritage speakers. The International Journal of Bilingualism, OnlineFirst.

Franco, Jon (2000). Agreement as a continuum: The case of Spanish pronominal clitics. In F. Beukema \& M. den Dikken (eds.), Clitic phenomena in European languages, pp. 147-189. Amsterdam: Benjamins.

Frota, S., \& Vigário, M. (2001). On the correlates of rhythmic distinctions: the European/Brazilian Portuguese case. Probus, 13, 247-275.

Gathercole, V. C. M. (2007). Miami and North Wales, so far and yet so near: Constructivist account of morphosyntactic development in bilingual children. International Journal of Bilingual Education and Bilingualism, 10, 224247.

Gathercole, V. C. M., \& Thomas, E. M. (2009). Bilingual first-language development: Dominant language takeover, threatened minority language take-up. Bilingualism: Language and Cognition, 12, 213-237.

Genesee, F., \& Nicoladis, E. (2006). Bilingual acquisition. In E. Hoff \& M. Shatz (eds.), Handbook of language development, pp. 324-342. Oxford: Blackwell.

Grolla, E. (2006). The Acquisition of A- and A'-bound pronouns in Brazilian Portuguese. In V. Torrens \& L. Escobar (eds.), The acquisition of syntax in Romance languages, pp. 227250. Amsterdam: John Benjamins.

Halliday, M. A. K. (1978). Language as social semiotic: The social interpretation of language and meaning. Edward Arnold: London.

Kaufman, D., \& Aronoff, M. (1991). Morphological disintegration and reconstruction in first language attrition. In H. W. Seliger \& R. M. Vago (eds.), First language attrition, pp. 175-188. Cambridge: Cambridge University Press.

Keating, G., VanPatten, B., \& Jegerski, J. (2011). Who was walking on the beach? Anaphora resolution in Spanish heritage speakers and adult second language learners. Studies in Second Language Acquisition, 33, 193-221. 
Kim, J.-H., Montrul, S., \& Yoon, J. (2009). Binding interpretation of anaphors in Korean heritage speakers. Language Acquisition, 16, 3-35.

Kupisch, T. (2012). Specific and generic subjects in the Italian of German-Italian simultaneous bilinguals and L2 learners. Bilingualism: Language and Cognition, 15, 736-756.

Lesaux, N. K., \& Siegel, L. S. (2003). The development of reading in children who speak English as a second language. Developmental Psychology, 39, 1005-1119.

Magro, C. (2007). Clíticos: Variações sobre o tema. Ph.D. Dissertation. University of Lisbon.

Martins, A. M. (1994). Cliticos na Història do Português, Ph.D. dissertation, University of Lisbon.

Meisel, J. M. (2001). The simultaneous acquisition of two first languages: Early differentiation and subsequent development of grammars. In J. Cenoz \& F. Genesee (eds.), Trends in bilingual acquisition, pp. 11-41. Amsterdam: John Benjamins.

Meisel, J. M. (2011). First and second language acquisition. Cambridge: Cambridge University Press.

Montrul, S. (2004). Subject and object expression in Spanish heritage speakers: A case of morpho-syntactic convergence. Bilingualism: Language and Cognition, 7, $1-18$.

Montrul, S. (2008). Incomplete acquisition in bilingualism: Reexamining the age factor. Amsterdam: John Benjamins.

Montrul, S. (2010a). Dominant language transfer in adult second language learners and heritage speakers. Second Language Research, 26, 293-327.

Montrul, S. (2010b). How similar are adult second language learners and Spanish heritage speakers? Spanish clitics and word order. Applied Psycholinguistics, 31, 167207.

Montrul, S., \& Polinsky, M. (2011). Why not heritage speakers? Linguistic Approaches to Bilingualism, 1, 58-62.

Müller, N., \& Hulk, A. (2001). Crosslinguistic influence in bilingual language acquisition: Italian and French as recipient languages. Bilingualism: Language and Cognition, 4, 1-21.

O'Grady, W., Lee, M., \& Choo, M. (2001). The acquisition of relative clauses by heritage and nonheritage learners of Korean as a second language: A comparative study. Journal of Korean Language Education, 12, 283-294.

Oller, D. K., \& Eilers, R. E. (2002). Balancing interpretations regarding effects of bilingualism: Empirical outcomes and theoretical possibilities. In D. K. Oller \& R. E. Eilers (eds.), Language and literacy in bilingual children, pp. 281-292. Clevedon, UK: Multilingual Matters.

Pascual y Cabo, D., \& Rothman, J. (2012). The (il)logical problem of heritage speaker bilingualism and incomplete acquisition. Applied Linguistics, 33, 450-455.

Pires, A., \& Rothman, J. (2009). Disentangling sources of incomplete acquisition: An explanation for competence divergence across heritage grammars. International Journal of Bilingualism, 13, 211-238.

Polinsky, M. (2006). Incomplete acquisition: American Russian. Journal of Slavic Linguistics, 14, 191-262.

Polinsky, M. (2008). Russian gender under incomplete acquisition. Heritage Language Journal, 6, 40-71.
Polinsky, M. (2011). Reanalysis in adult heritage language. New evidence in support of attrition. Studies in Second Language Acquisition, 33, 305-328.

Raposo, E. P. (1986). On the null object construction in European Portuguese. In O. Jaeggli \& C. Silva-Corvalán (eds.), Studies in Romance linguistics, pp. 373-390. Dordrecht: Foris.

Raposo, E. P. (2000). Clitic positions and verb movement. In J. Costa (ed.), Portuguese syntax: New comparative studies, pp. 266-297. Oxford: Oxford University Press.

Rothman, J. (2007). Heritage speaker competence differences, language change, and input type: Inflected infinitives in heritage Brazilian Portuguese. The International Journal of Bilingualism, 11, 359-389.

Santos, A. L., \& Flores, C. (2012). Comparing heritage speakers and late L2-learners of European Portuguese: Verb movement, VP ellipsis and adverb placement. Paper presented at the Workshop on Crosslinguistic Influence in Non-Native Language Acquisition, Faculdade de Ciências Sociais e Humanas da Universidade Nova de Lisboa, Lisbon, June 29-30, 2012.

Schlyter, S. (1993). The weaker language in bilingual SwedishFrench children. In K. Hyltenstam \& A. Vilberg (eds.), Progression and regression in language, pp. 289-308. Cambridge: Cambridge University Press.

Seliger, H. W. (1989). Deterioration and creativity in childhood bilingualism. In K. Hylstenstam \& L. K. Obler (eds.), Bilingualism across the lifespan, pp. 173-184. Cambridge: Cambridge University Press.

Senra, T. (2011). Sprachkompetenz der 2. Generation portugiesischer Migranten in Hamburg: unvollständiger Erwerb? Master's thesis, University of Minho, Portugal.

Silva-Corvalán, C. (1994). Language contact and change. New York: Oxford University Press.

Sorace, A. (2004). Native language attrition and developmental instability at the syntax-discourse interface: Data, interpretations and methods. Bilingualism: Language and Cognition, 7, 143-45.

Sorace, A. (2011). Pinning down the concept of interface in bilingualism. Linguistic Approaches to Bilingualism, 1, 133.

Suñer, M. (1988). The role of agreement in clitic-doubled constructions. Natural Language and Linguistic Theory, 6, 391-434.

Tsimpli, I., Sorace, A., Heycock, C., \& Filiaci, F. (2004). First language attrition and syntactic subjects: A study of Greek and Italian near-native speakers of English. International Journal of Bilingualism, 8, 257-277.

Unsworth, S. (2013). Assessing the role of current and cumulative exposure in simultaneous bilingual acquisition: The case of Dutch gender. Bilingualism: Language and Cognition, 16, 86-110.

Wexler, K., Gavarró, A., \& Torrens, V. (2004). Feature checking and object clitic omission in child Catalan and Spanish. In R. Bok-Bennema, B. Hollebrandse, B. KampersManhe \& P. Sleeman (eds.), Romance Languages and Linguistic Theory 2002: Selected papers from 'Going Romance', Groningen, 28-30 November 2002, pp. 253269. Amsterdam: John Benjamins. 